AVALIAÇÃo DE PLANTAS MEDICINAIS NO COMBATE A MASTITE BOVINA

\author{
Samoel Alexandre Fonseca Dantas
}

Aluno do IFRN. Bolsista de IC. E-mail: fonsecadantas@bol.com.br

Larissa Veras Torquato Sena

Aluna do IFRN. Bolsista de IC. E-mail: larissatsena@hotmail.com

Dyego Jones Alves de Melo

Aluno do IFRN. Bolsista de IC. E-mail: dyegojonesam@hotmail.com

Fabio Teixeira Duarte

Professor do IFRN - Campus Ipanguaçu. E-mail: fabioduarte@cefetrn.br

Adriano Soares de Carvalho

Professor do IFRN - Campus Ipanguaçu. E-mail: adriano@cefetrn.br

\title{
RESUMO
}

Mastite é a inflamação da glândula mamária da vaca, sendo infecto-contagiosa que mais se propaga nos rebanhos e geralmente causando grandes prejuízos a indústria de laticínios, pode ser provocada por cerca de 130 agentes envolvidos, dentre eles, bactérias, vírus, algas e fungos. As bactérias são os agentes de maior importância como causa da doença. Por esta razão o IFRN aprovou o projeto para avaliação de qual o melhor tratamento com plantas medicinais nativas a ser utilizada na cura da mastite. O enfoque do resultado do projeto estaria direcionado para o diagnóstico e cura da doença na criação de rebanhos leiteiros de pequenos produtores do Vale do Assu. Para a realização desse diagnóstico e investigação sobre planta medicinal a ser utilizado nas vacas acometidas pela mastite, serão realizados exames de antibiograma para investigar a susceptibilidade da bactéria a determinadas plantas. Nos resultados preliminares, realizados em laboratório, foi identificado que a casca do caule do cajueiro roxo (Anacardium occidentale L) tem ação antibiótica e a flor da catingueira (Caesalpinia pyramidalis) inibe a proliferação das bactérias existentes no leite de vacas infectadas com mastite sub-clínica. Desta maneira, sugere-se a possibilidade do uso deste vegetal no combate e cura a esta doença.

PALAVRAS-CHAVE: Mastite, Antibiograma, Plantas medicinais. 


\section{AVALIAÇÃO DE PLANTAS MEDICINAIS NO COMBATE A MASTITE BOVINA}

\section{INTRODUÇÃO}

Mastite é a inflamação na glândula mamária (Costa, 1998), sendo uma doença infectocontagiosa que mais se propaga nos rebanhos e geralmente causando grandes prejuízos a indústria de laticínios, pode ser provocada por cerca de 130 agentes envolvidos dentre eles bactérias, vírus, algas e fungos (Watts, 1998). As bactérias são os agentes de maior importância como causa da doença (Langoni, et al., 1998). A sua ocorrência envolve três fatores principais: a resistência da vaca, o agente patogênico e o ambiente. No entanto, podem ser controlados por medidas higiênicas e profiláticas (Scarlatelli, 1998).

Uma das formas de se diagnosticar esta doença é através do isolamento bacteriano e respectivo antibiograma que são ferramentas imprescindíveis n dia-a-dia da granja leiteira. Além de serem úteis para confirmar o diagnóstico clínico, os resultados desses testes possuem grande importância e são aplicados na triagem dos fármacos, ou seja, escolha do antibiótico de maior eficiência no combate de doença. Os resultados laboratoriais demonstram através de seus resultados erro de manejo e sugerem possíveis correções, que podem reduzir sensivelmente as recidivas (Fernandes, 2006). Estes exames são de alto custo bem como os tratamentos alopáticos propostos. Este fato onera bastante a produção do pequeno produtor.

A utilização de ervas medicinais esta em considerável crescimento em todo mundo. Nas últimas décadas a procura pelas diversas modalidades de medicina alternativa, cientificamente denominada "medicina complementar". A fitoterapia é a forma de medicina mais ancestral e disseminada. No Brasil, tradicionalmente usadas por populações rurais carentes, as plantas medicinais vêm sendo largamente utilizadas também nos centros urbanos e tratamentos veterinários, por pacientes de todo nível socioeconômico e cultural. Alias, o mercado de fitoterápicos movimenta cifras da ordem de bilhões de dólares anualmente na Europa e América do Norte. Uma parcela significativa dos usuários de medicina complementar busca o tratamento de diversas doenças (MENON-MIYAKE, et al 2005).

\section{REVISÃO BIBLIOGRAFICA}

Mamite ou mastite é a inflamação da glândula mamária (Costa, 1998), sendo uma doença infecto-contagiosa que se propaga no rebanho e geralmente é provocada por cerca de 130 agentes envolvidos dentre eles bactérias, vírus, alagas e fungos (Watts, 1998). As bactérias são os agentes de maior importância como causa da doença (Langoni et al., 1998). A sua ocorrência envolve três fatores principais: a resistência da vaca, o agente patogênico e o ambiente. No entanto, podem ser controlados por medidas higiênicas e profiláticas (Scarlatelli, 1998).

A inflamação se traduz por alterações na composição do leite e presença de células somáticas (CCS) em quantidades elevadas (Prestes et al., 2003). Esta inflamação pode aparecer quando a vaca está em lactação e durante o período seco. 
A mamite é a doença que mais acomete e que mais prejuízos causam para o rebanho leiteiro em todo o mundo (Pyorala, 2002).

Os danos que a doença provoca são traduzidos nos seguintes prejuízos:

1. Diminuição da produção de leite;

2. Perda de um ou mais quartos do úbere;

3. Acidez do leite, quase sempre rejeitado pelos laticínios;

4. Desvalorização comercial da vaca leiteira, que passa a ser animal de corte;

5. Pode causar a morte do animal, por infecção irreversível.

Como se deduz, a mamite deve ser considerada muito mais uma doença de caráter econômico. A essa doença pode ser caracterizada de duas maneiras quanto o diagnostico: mastite clínica, quando são observados os sintomas da doença e a aguda ou sub-clínica quando ainda não se observa os sintomas da doença (Mendonça, 1999). A clínica caracteriza-se por apresentar o úbere inchado, de cor avermelhada, dolorido e quente; o leite apresenta-se aguado ou grosso, de cor amarelada, com flocos ou coágulos; à medida que a vaca diminui a produção de leite, diminui o apetite e perde peso. A ausência destes sintomas, entretanto com redução na produção e alteração da composição do leite, caracteriza mastite sub-clínica, que por sua vez somente pode ser detectada através de exames de laboratório ou testes executados ao pé da vaca.

Quanto ao tipo de agente causador a mamite pode ser classificada em: Mamite ambiental, causada por microrganismos que estão no ambiente em que a vaca vive principalmente onde há acúmulo de esterco, urina, barro e camas orgânicas. Caracteriza-se por alta incidência de casos clínicos, geralmente de curta duração. É causada por bactérias dos grupos dos coliformes, estreptococos ambientais e enterococos, sendo transmitida através do ambiente contaminado.

Mamite contagiosa, causada por microrganismos contagiosos chamados de "vaca dependente” que estão no interior da glândula mamária e na pele dos tetos. A transmissão ocorre principalmente durante a ordenha dos animais, por meio das teteiras, das mãos dos ordenhadores e de panos utilizados na limpeza e secagem dos tetos. Manifesta-se principalmente sob a forma subclínica.

Vacas com mamite clínica devem ser tratadas imediatamente com antibióticos adequados e produtos à base de enzimas. Para definir o melhor antimicrobiano deve-se realizar a cultura e o antibiograma do leite do quarto mamário afetado. O leite para o exame deve ser coletado antes de qualquer tratamento. A antibioticoterapia é o procedimento mais utilizado no tratamento da mastite bovina (Pinto et al., 2001).

O antibiograma é um teste que oferece como resultado padrões de resistência ou susceptibilidade, de uma bactéria específica, a antimicrobianos (antibióticos ou quimioterápicos). Os resultados desses testes possuem grande importância e são aplicados na triagem dos fármacos, daí a necessidade da opção por um antibiótico de alto poder bactericida, que atue no maior número possível de agentes causadores de mastites. A aferição de sensibilidade é fundamental para a certeza de se estar utilizando o produto certo e que melhor se aplica no combate aos agentes de mastite em cada propriedade (Fernandes, 2006). 
O isolamento bacteriano e respectivo antibiograma são ferramentas imprescindíveis no diaa-dia da granja leiteira. Além de serem úteis para confirmar o diagnóstico clínico, os resultados laboratoriais demonstram através de seus resultados erros de manejo sugerem possíveis correções, que podem reduzir sensivelmente as recidivas (Fernandes, 2006).

Em decorrência da diversidade de agentes etiológicos envolvidos em mastites, a utilização de exames microbiológicos e posteriormente testes de sensibilidade antimicrobiana in vitro são medidas indicadas antes da eleição do tratamento, pois esta diversidade microbiológica pode ter diferentes respostas frente ao medicamento a ser utilizado. E os resultados de resistência e sensibilidade intermediária com algumas bactérias observadas em Silva et al, 2008, confirmam a importância da realização de antibiograma, para evitar o uso de antibióticos ineficientes.

O objetivo deste estudo é identificar fitoterápicos com ação antibiótica sobres bactérias isoladas a partir de leite de vacas com mastite, através da realização de antibiograma pela técnica de difusão em Ágar.

\section{METODOLOGIA}

Material

- Tubos coletores;

- $\quad$ Placas de Petri;

o Meio de cultura;

- Plantas medicinais

o Cajueiro roxo - Anacardium ocidentales

o Catingueira - Caesalpinia pyramidalis

o Cabacinha - Luffa operculata Cogn

o Ubiratanha-Pseudobombax margintum

- Papel filtro;

- Álcool Etílico;

- Frascos para meio de cultura;

- Agar

Equipamentos

- Destilador;

- Fluxo laminar;

- Autoclave;

- Estufas;

- Microondas

Coleta do Leite

- A coleta de leite foi realizada através de ordenha manual em vaca que apresentaram mastite clinica e subclínicas utilizando tubos de vidro altoclavados.

Antibiograma

- Os decoctos foram feitos segundo orientações da Farmacopéia brasileira utilizado $1 \mathrm{~g}$ do vegetal moído em $10 \mathrm{~mL}$ de água destilada e autoclavada por $15 \mathrm{~min}$. 
- Para realização do antibiograma, foi feito inicialmente uma cultura de bactéria visando o isolamento de colônia. Desta maneira, em placas de vidro contendo meio sólido foi semeados $100 \mu \mathrm{L}$ de leite com auxílio de bolinhas de vidro, logo após, foram levadas a estufa a $37{ }^{\circ} \mathrm{C}$ onde ficaram por 24 horas. Deste cultivo foi possível isolar colônias bacterianas do leite.

- As colônias isoladas foram cultivadas em tubos de ensaio com meio líquido sobre as mesmas condições. Utilizando placas com meio de cultivos sólido o caldo bacteriano foi inoculado em toda extensão da placa com o auxílio de algodão e em seguida depositado os discos de papel filtro ésteres impregnados com o decocto das quatro espécies vegetais a serem analisadas, como controle negativo foi adicionado um disco contendo água destilada autoclavada. Após a realização do procedimento as placas foram incubadas a $37^{\circ} \mathrm{C}$ por 24 horas.

- A leitura do antibiograma foi realizada através da medida dos halos formados ao redor dos discos. O resultado foi expresso como atividade: antibiótica, inibidor de crescimento ou sem atividade antibacteriana.

Tabela 1: Plantas medicinais utilizadas

\begin{tabular}{|c|c|c|c|c|c|}
\hline Família & Espécie & $\begin{array}{c}\text { Nome } \\
\text { vernacular }\end{array}$ & $\begin{array}{l}\text { Atividade } \\
\text { microbiana }\end{array}$ & $\begin{array}{c}\text { Parte } \\
\text { utilizada }\end{array}$ & Hábito \\
\hline 1. Anacardiaceae & $\begin{array}{l}\text { Anacardium } \\
\text { ocidentale } L\end{array}$ & Cajueiro & Antibiótiva & Casca & Árvore \\
\hline 2. Fabaceae & $\begin{array}{l}\text { Caesalpinia } \\
\text { pyramidalis }\end{array}$ & Catingueira & $\begin{array}{l}\text { Inibidora de } \\
\text { crescimento }\end{array}$ & Flor & /arbusto \\
\hline 3. Cucurbitaceae & $\begin{array}{c}\text { Luffa } \\
\text { operculata }\end{array}$ & Cabacinha & $\begin{array}{l}\text { Sem ação } \\
\text { antibiótica }\end{array}$ & Fruto & Liana \\
\hline 4. Bombacaceae & $\begin{array}{l}\text { Pseudobombax } \\
\text { margintum }\end{array}$ & Ubiratanha & $\begin{array}{l}\text { Sem ação } \\
\text { antibiótica }\end{array}$ & Casca & Árvore \\
\hline $\begin{array}{l}5 \text {. Leguminosae- } \\
\text { Caesalpinoideae }\end{array}$ & $\begin{array}{l}\text { Caesalpineae } \\
\text { férrea }\end{array}$ & Pau ferro & $\begin{array}{l}\text { Sem ação } \\
\text { antibiótica }\end{array}$ & Folha & Árvore \\
\hline 6. Punicáceas & $\begin{array}{c}\text { Punica } \\
\text { granatum }\end{array}$ & Romã & & Fruto & Arbusto \\
\hline
\end{tabular}

\section{ANÁLISE E INTERPRETAÇÃO DOS DADOS}

Foram investigadas as atividades antibióticas de quatro plantas sobre bactérias provindas de leite de vacas com infecção mastítica. As quatro espécies vegetais são utilizadas na medicina popular como plantas medicinais de ação antiinflamatória. A análise dos resultados obtidos através do antibiograma mostrou que a ubiratanha (Pseudobombax margintum) e a cabacinha (Luffa operculata Cogn) não possuem ação antibiótica contra as bactérias que causam mamite. Entretanto, a análise do infuso das flores da cantigueira (Caesalpinia pyramidalis) apresentou ação de inibidora de crescimento bacteriano, no entanto, não foi capaz de combater totalmente o patógeno (ver tabela 1). Das plantas estudas, a que apresentou melhor atividade antimicrobiana foi o cajueiro (Anacardium ocidentale $L$ ), pois a análise dos halos formados mostra que esta planta possui ação antibiótica sobre bactérias que causam mamite em vacas. 


\section{CONCLUSÕES}

Ao termino deste trabalho obtivemos resultados interessantes $\mathrm{n}$ a descoberta de novos meios mais acessíveis e naturais para tratamento e cura da mastite. Pois a análise de nossos resultados, em teste de antibiograma, mostrou a formação de halo de crescimento bacteriano no entorno do disco contendo a infusão da casca do cajueiro (Anacardium ocidentale $L$ ). O resultado demonstra que este vegetal possui atividade antibacteriana sobre bactérias que causam a mastite. Sendo assim, podemos inferir uma possível utilização deste infuso no controle da mamite.

Desta maneira nossa pesquisa estará contribuindo para o fortalecimento da agropecuária no Vale do Assu. Pois apresenta soluções de baixo custo para curas desta doença. Favorecendo assim, o desenvolvimento de rebanhos mais saudáveis devido ao controle da mamite e possibilitando uma produção leiteira de melhor qualidade e sem prejuízos para o pequeno produtor.

\section{REFERÊNCIAS BIBLIOGRAFICAS}

COSTA, E. O. Importância da mastite na produção leiteira do Brasil. Revista de Educação Continuada do CMRV-SP. São Paulo, v.1, p.3-9, 1998.

BRITO, M. A. V. P.; BRITO, J. R. F.; RIBEIRO, M. T.; VEIGA, V. M. O. Padrão de infecção intramamária em rebanhos leiteiros: exame de todos os quartos mamários das vacas em lactação. Arquivo Brasileiro de Medicina Veterinária e Zootecnia. v.51, n.2, p.129-135, 1999.

BRITO, M. A. V. P.; BRITO, J. R. F.; SILVA, M. A. S.; CARMO, R. A. Concentração mínima inibitória de dez antimicrobianos para amostras de Staphylococcus aureus isoladas de infecção intramamária bovina. Arquivos Brasileiros de Medicina Veterinária e Zootecnia. v.53, n.5, p.531-537, 2001.

FERNANDES, D. Diagnóstico laboratorial em mastites bovinas: Sua real importância e aplicação prática. Atualização Técnica 33, Div. Agropec. Pfizer, 2006.

LANGONI, H.; DOMINGUES, P.F.; SILVA, A.V. et al. Aspectos etiológicos na mastite bovina.

Revista Brasileira de Medicina Veterinária, v.20, p.204-210, 1998.

MENDONÇA, C. L.; FIORAVANT, M. C. S.; SILVA, J. A. B. A. Etiologia da mastite bovina. Veterinária Notícias, v.5, n.1, p.107-118, 1999.

PRESTES, D. S.; FILATI, A.; CECIM, M. S. Suscetibilidade à mastite: Fatores que a influenciam- Uma revisão. Revista Faculdade Zootecnia Veterinária e Agronomia. v.9, n.1, p-48-59, 2003.

PINTO, M. S.; FARIA, J. E. de; MESSAGE, D.; CASSINI, S. T. A.; PEREIRA, C. S.; GIOSO, M. M. Efeito de extratos de própolis verde sobre bactérias patogênicas isoladas do leite de vacas com mastite. Braz. J. vet. Reserch animal Science, v. 38, n.6, p.278-283, 2001. 
PYORALA, S. New strategies to prevent mastitis. Reproduction in Domestic Animals, Belfast, v.37, n.4, p.211-216, 2002.

SILVA, C. C.; VARGAS, C. G,; LUND, R. G.; LADEIRA, S.; GONZALES, H. de L.; NASCENTE, P.da S. Suscetibilidade in vitro de bactérias causadoras de mastite frente antibióticos. Conhecimentos sem fronteiras. 2008.

TRABULSI, LR; ALTERTHUM, F (Eds.). Microbiologia. 4a Ed. São Paulo: Atheneu, 2004.

TORRES, C. Lectura interpretativa del antibiograma de cocos grampositivos. Enferm. Infec. Microbiol. Clin., v. 20, n. 7, p. 354-364. 2002.

WATTS, J. L. Etiological agents of bovine mastitis. Veterinary Microbiology, v.16, p.4146, 1998. 